\title{
Quaternary Geologic Map of the North-Central Part of the Salinas River Valley and Arroyo Seco, Monterey County, California
}

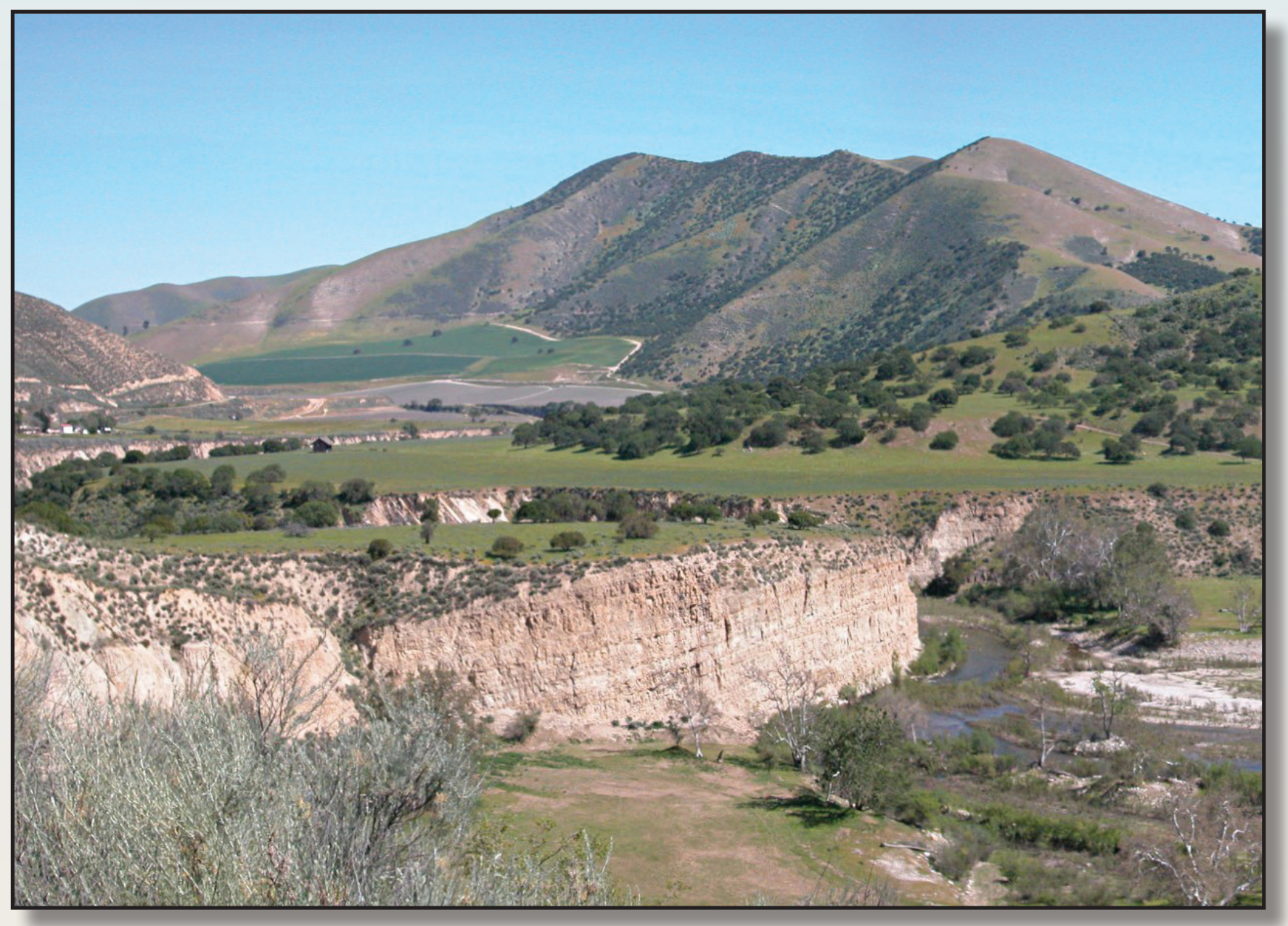

Pamphlet to accompany

Scientific Investigations Map 3260 
Cover: View looking downstream at a well-preserved sequence of late Pleistocene and inset Holocene strath terraces. Where Arroyo Seco has eroded Tertiary marine sediments, primarily Monterey shale, a broad valley has formed. Each terrace records a floodplain eroded into the bedrock and is capped by rounded gravel derived from the more resistant basement rocks upstream. Photograph by Tony Garcia, California Polytechnic University, San Luis Obispo, 2012. 


\section{Quaternary Geologic Map of the North-Central Part of the Salinas River Valley and Arroyo Seco, Monterey County, California}

By Emily M. Taylor and Donald S. Sweetkind

Pamphlet to accompany

Scientific Investigations Map 3260 


\title{
U.S. Department of the Interior SALLY JEWELL, Secretary
}

\section{U.S. Geological Survey Suzette M. Kimball, Acting Director}

\author{
U.S. Geological Survey, Reston, Virginia: 2014
}

For more information on the USGS - the Federal source for science about the Earth, its natural and living resources, natural hazards, and the environment, visit http://www.usgs.gov or call 1-888-ASK-USGS.

For an overview of USGS information products, including maps, imagery, and publications, visit http://www.usgs.gov/pubprod

To order this and other USGS information products, visit http://store.usgs.gov

Any use of trade, firm, or product names is for descriptive purposes only and does not imply endorsement by the U.S. Government.

Although this information product, for the most part, is in the public domain, it also may contain copyrighted materials as noted in the text. Permission to reproduce copyrighted items must be secured from the copyright owner.

Suggested citation:

Taylor, E.M., and Sweetkind, D.S., 2014, Quaternary geologic map of the north-central part of the Salinas River Valley and Arroyo Seco, Monterey County, California: U.S. Geological Survey Scientific Investigations Map 3260, 13 p., 2 sheets, scales 1:24,000 and 1:50,000, http://dx.doi.org/10.3133/sim3260.

ISSN 2329-132X (online) 


\section{Contents}

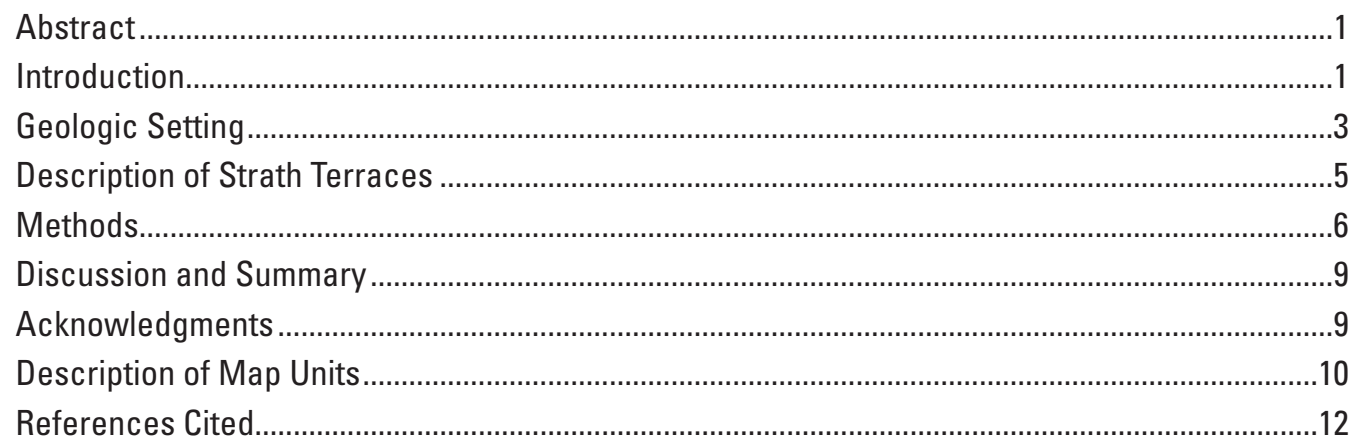

\section{Figures}

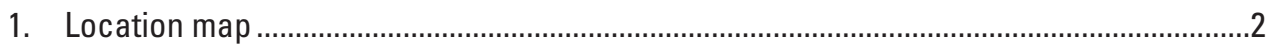

2. Photographs showing stream-valley morphology of Arroyo Seco .....................................3

3. Location of Arroyo Seco inset map of Quaternary-age strath terraces...........................

4. Photographs showing lag gravels and strath terraces ......................................................5

5. Buried terrace gravel exposed in road cut in Arroyo Seco...................................................6

6. Unique soils are developed on the terrace surfaces ..........................................................

7. Stream gradient profile of terrace surfaces along Arroyo Seco ......................................8

\section{Conversion Factors}

Inch/Pound to SI

\begin{tabular}{lcl}
\hline Multiply & By & To obtain \\
\hline & Length & \\
\hline inch (in.) & 2.54 & centimeter $(\mathrm{cm})$ \\
inch (in.) & 25.4 & millimeter $(\mathrm{mm})$ \\
foot (ft) & 0.3048 & meter $(\mathrm{m})$ \\
mile (mi) & 1.609 & kilometer $(\mathrm{km})$ \\
yard (yd) & 0.9144 & meter $(\mathrm{m})$ \\
\hline
\end{tabular}





\title{
Quaternary Geologic Map of the North-Central Part of the Salinas River Valley and Arroyo Seco, Monterey County, California
}

\author{
By Emily M. Taylor and Donald S. Sweetkind
}

\begin{abstract}
Arroyo Seco, a perennial drainage in the central Coast Range of California, records a sequence of strath terraces. These terraces preserve an erosional and depositional history, controlled by both climate change and regional tectonics. These deposits have been mapped and correlated on the basis of field investigations, digital terrain analysis, stream gradient profiles, evaluation of published regional soil maps, and satellite imagery. Seven of the strath terraces and associated alluvial fans have been dated by optically stimulated luminescence (OSL) or infrared stimulated luminescence (IRSL). The OSL and IRSL dates on seven of the strath terraces and associated alluvial fans in Arroyo Seco are approximately $>120 \mathrm{ka},>65 \mathrm{ka}, 51-46 \mathrm{ka}, 36-35 \mathrm{ka}, 9 \mathrm{ka}$, and 2-1 ka. These dates generally fall within the range of ages reported from many well-dated marine terraces on the California coast that are formed during sea-level high stands. Tectonic movements, consistently upward, result in a constantly and slowly emerging coast line, however, the regional effects of climate change and resulting eustatic sea-level rises are interpreted as the driving mechanism for erosion and aggradation in Arroyo Seco.
\end{abstract}

\section{Introduction}

Arroyo Seco, a perennial drainage in the Santa Lucia Range of the central Coast Range of California (fig. 1) adjacent to the Salinas River valley, records in its deposits a sequence of erosional strath terraces. Arroyo Seco cuts a narrow canyon in resistant bedrock in the uplands of the Santa Lucia Range, but opens eastward to a broad, meandering 16-kilometer- (km-) long valley where the drainage flows over more easily erodible sedimentary rocks. Arroyo Seco declines in elevation from about 250 meters (m) at the canyon mouth to $50 \mathrm{~m}$, where it flows into the Salinas River valley. Arroyo Seco is a perennial stream and one of the largest tributary drainages of the Salinas River. The Salinas River valley is drained by the 275-km-long Salinas River, as measured from its headwaters in San Luis Obispo County northwards to Monterey
Bay. Based on data from oil and gas exploration drill holes and deep water wells, the Salinas River valley is filled with as much as 1,800 $\mathrm{m}$ of Tertiary and Quaternary marine and terrestrial sediments (Durham, 1974). Preserved stream-terrace deposits within and near sedimentary basins are a record of erosional history that provides a context for downstream basin aggradation, basin-margin fault-related uplift, and paleoclimate events. Understanding the erosion of sediment from Arroyo Seco contributes to understanding the evolution of sedimentation in the northern part of the Salinas River valley. Arroyo Seco erosional strath terraces mark stable periods between base-level changes driven by tectonics or sea-level fluctuations, an indirect result of climate change. Seven of the terraces have been dated by feldspar infrared stimulated luminescence (IRSL) or quartz optically stimulated luminescence (OSL) and range in age from $1 \mathrm{ka}$ to $>120 \mathrm{ka}$. We combined terrain analysis of a digital elevation model with traditional geologic field methods, and relative age and dating techniques to develop a Quaternary geologic map to help interpret the long-term erosional history of Arroyo Seco drainage.

The mapped area covers six 7.5-minute U.S. Geological Survey (USGS) quadrangles or an area of about 33 by $28 \mathrm{~km}$. Previous detailed bedrock mapping was done by Durham (1963, 1970), Page (1998) and by Dibblee and Minch (2006a-e; 2007). Rosenberg and Clark (2009) updated the mapping of the Rinconada and Reliz faults. Quaternary geologic mapping of Arroyo Seco and the northern Salinas River valley areas was done as part of graduate studies (Snetsinger, 1962; Dohrenwend, 1974, 1979; Tinsley, 1975; Tinsley and Dohrenwend, 1979). Our new mapping provides a detailed stratigraphic history of incision and deposition from the early Pleistocene to the present.

Infiltration from the Salinas River and its tributaries is the source of irrigation water in this productive agricultural region. Irrigation water is pumped from the shallow aquifers at depths of about 55 and $120 \mathrm{~m}$ (Durbin and others, 1978); however, these have become intruded by seawater, especially between Castroville and Salinas (north of the map area). In those areas, groundwater is mainly pumped from the "deep" aquifer, which is approximately $275-400 \mathrm{~m}$ deep. In contrast, 


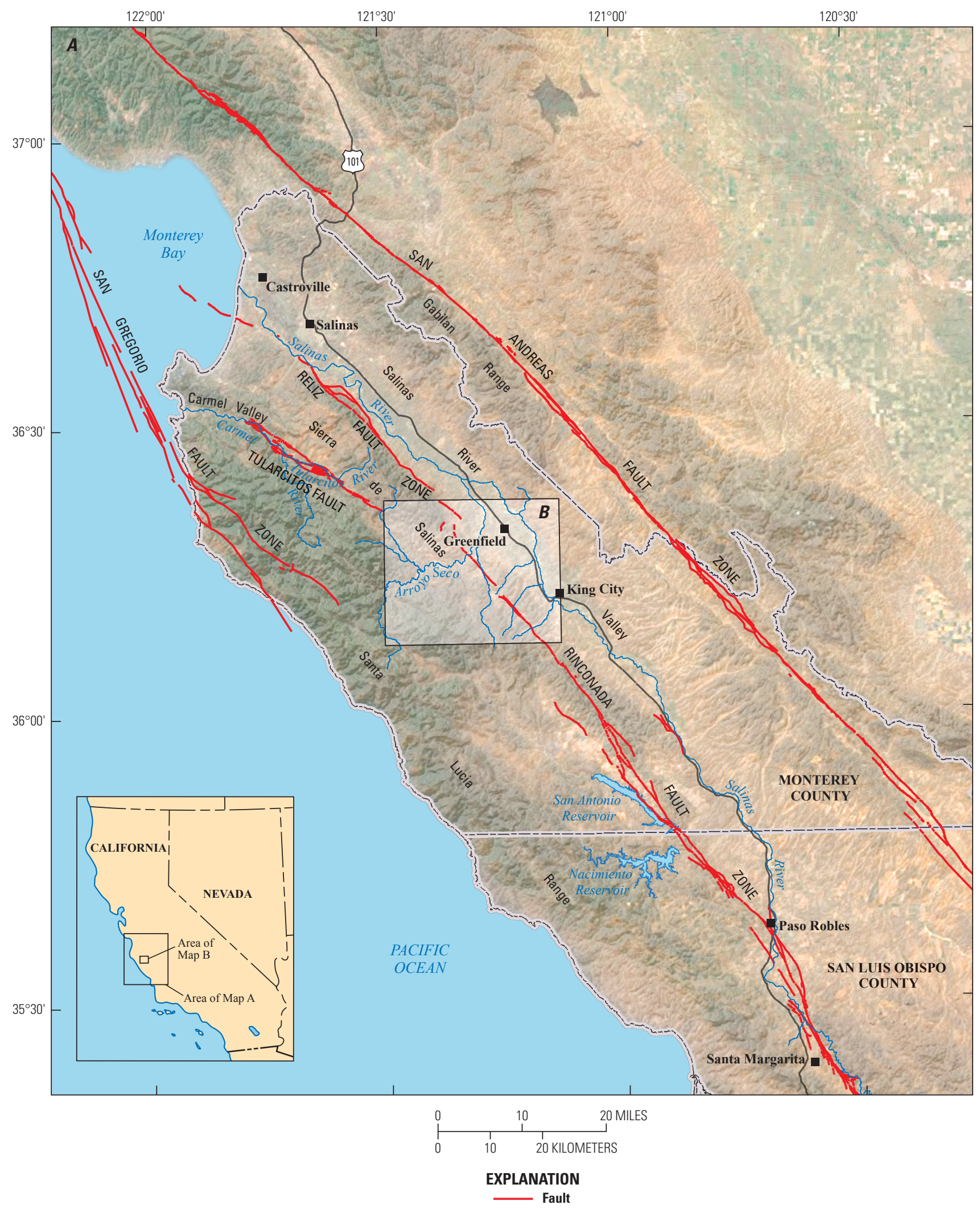

Figure 1. Location Map. Arroyo Seco is located in Monterey County in coastal, central California. Arroyo Seco, in the Sierra de Salinas, is bound on the east by the Salinas River valley. 
near Arroyo Seco and King City areas, some wells pump from depths of less than 15 meters. The shallower depth has to do with these wells commonly tapping underflow from the Salinas River where groundwater is kept shallow by controlled releases from San Antonio and Nacimiento dams (L. Rosenberg, USGS, written commun., 2012). The deepest part of the Salinas basin is near the mouth of Arroyo Seco, where depth to pre-Tertiary basement is about $1,800 \mathrm{~m}$ (Durham, 1974; Graham, 1978). The saturated thickness in this area is about $450-600 \mathrm{~m}$, and the aquifer materials consist of Miocene to Pliocene sandstones within the Pancho Rico Formation, the Pliocene to middle Pleistocene Paso Robles Formation, and unconsolidated alluvium.

\section{Geologic Setting}

The Santa Lucia Range is part of the Salinian block-a structural block underlain by granitic and granitic-gneiss basement rocks - that lies west of the San Andreas fault system, in contrast to adjacent structural blocks that are characterized by basement rocks consisting of Franciscan Complex, Jurassic ophiolite, and upper Mesozoic forearc deposits (Reed and Hollister, 1936; Dibblee, 1973; Graham, 1978). Cretaceous and older crystalline granitic rock and associated metasedimentary rocks are here designated as $\mathrm{MzP}_{\mathbf{z}} \mathrm{ub}$, Paleozoic to Mesozoic undifferentiated basement (fig. 2). A sequence of Paleocene-Miocene marine sedimentary rocks, including the Monterey Formation, unconformably overlies the crystalline bedrock (Durham, 1963, 1970, 1974; Seiders and others, 1983). This sequence is here referred to as Tertiary marine sediments (Tms) (fig. 15, sheet 2). Successively overlying the Tms are the Miocene to Pliocene marine sediments of the Pancho Rico Formation (Tpr), a Pliocene nearshore regressive sandstone informally named the sandstone of San Ardo (Tsa) (Dibblee and Minch, 2006b, c; 2007), and Pliocene to middle Pleistocene nonmarine alluvial sediments of the Paso Robles Formation (QTpr) (Durham, 1970). Quaternary units are subdivided into alluvial deposits, fluvial and alluvial deposits, fluvial deposits, and minor eolian deposits. Mapped units are distinguished on the basis of stratigraphic order, elevation, and soil development (Soil Survey Staff, 2010) primarily based on the accumulation of secondary clay.
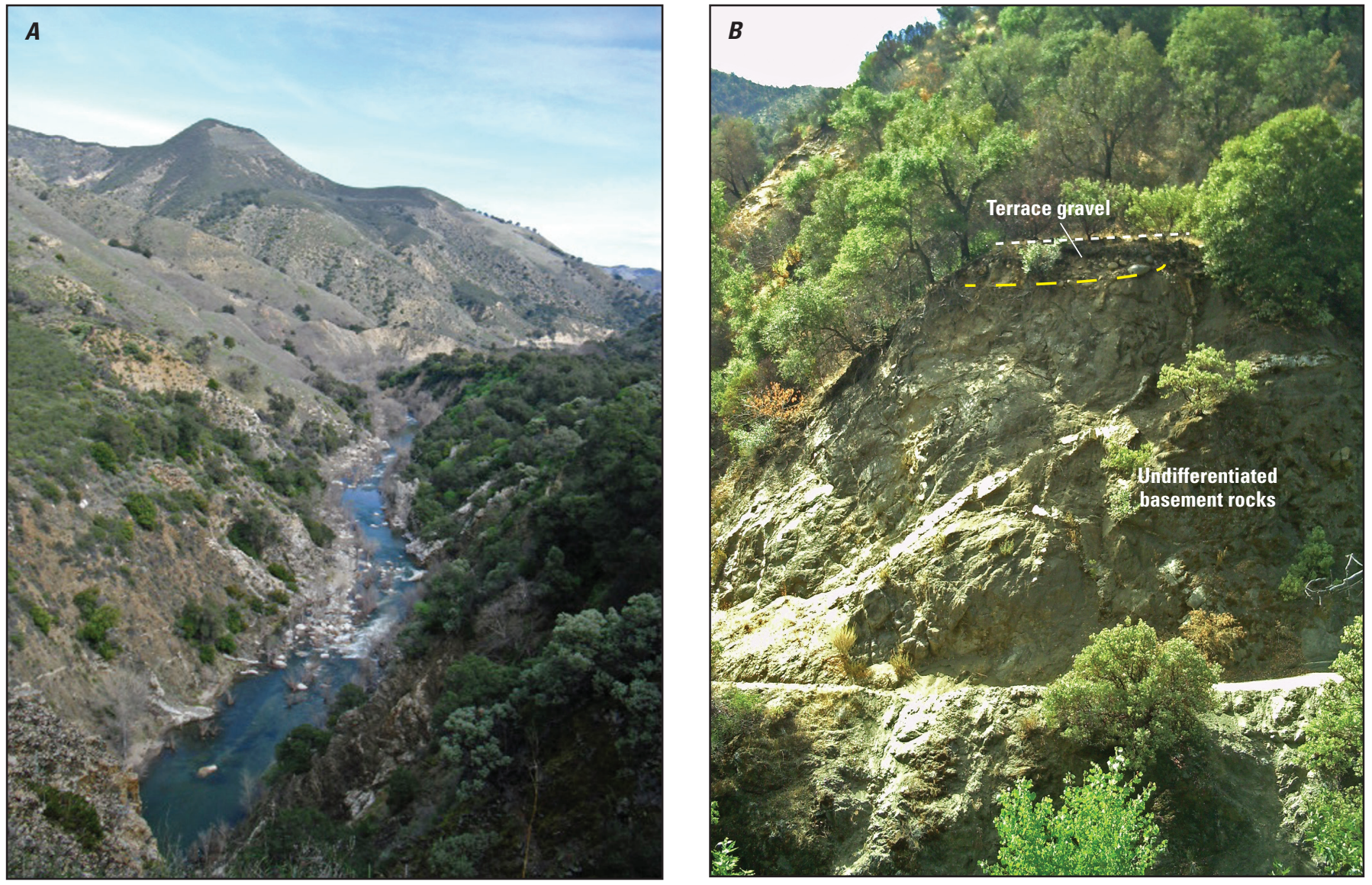

Figure 2. Photographs showing stream-valley morphology of Arroyo Seco. $A$, narrow canyon formed in the resistant basement rocks; $B$, terraces are preserved in the resistant basement rocks as narrow treads, typically less than $5 \mathrm{~m}$ wide. Dashed yellow line is top of bedrock and dashed white line indicates the terrace surface. 
Arroyo Seco cut a narrow canyon in bedrock through the Santa Lucia Range (fig. $2 A$ ) that opens to a broad 16-km-long valley (fig. 15, sheet 2). The narrow canyon is a result of erosion in relatively resistant basement rocks, primarily granitic and metasedimentary rocks that are Cretaceous and older in age. Arroyo Seco opens to a broad meandering drainage at the abrupt contact of the basement rock with the more easily erodible Paleocene- to Miocene-age Tertiary marine sediments (fig. $2 B$ ). Arroyo Seco declines in elevation from about $250 \mathrm{~m}$ at the canyon mouth to $50 \mathrm{~m}$, where it flows into the Salinas River valley.

Two major range-front faults intersect south of the confluence of Arroyo Seco and the Salinas River valley, near Monroe Canyon (figs. 1 and 3). The Reliz fault zone, a highangle reverse fault, trends northward, bounds the east side of the Sierra de Salinas, and extends to Monterey Bay (Durham, 1970; Rosenberg and Clark, 2009). Where the fault intersects
Arroyo Seco, there is no evidence for Quaternary offset (Durham, 1970; Rosenberg and Clark, 2009; fig. 13, sheet 2). North of Arroyo Seco, the Sierra de Salinas are partially flanked by older, undeformed (or scarcely deformed) fan deposits (Tinsley, 1975; fig. 2, sheet 1). Southward from Monroe Canyon, the Rinconada section, or "segment" as delineated by Dibblee (2006c), of the Rinconada fault extends to the Rinconada Mine near Santa Margarita (Rosenberg and Clark, 2009, p. 5). The Rinconada fault is a right-lateral fault, similar to the San Andreas Fault $25 \mathrm{~km}$ east, with offset as young as Holocene (Rosenberg and Clark, 2009). Where Monroe Creek and Thompson Canyon drainages intersect the valley floor, the stream drainages are offset to the north, indicating right-lateral movement on the Rinconada fault. The drainage offset has caused incision of alluvial fans that are late Pleistocene age, thus supporting regional evidence for Quaternary movement.

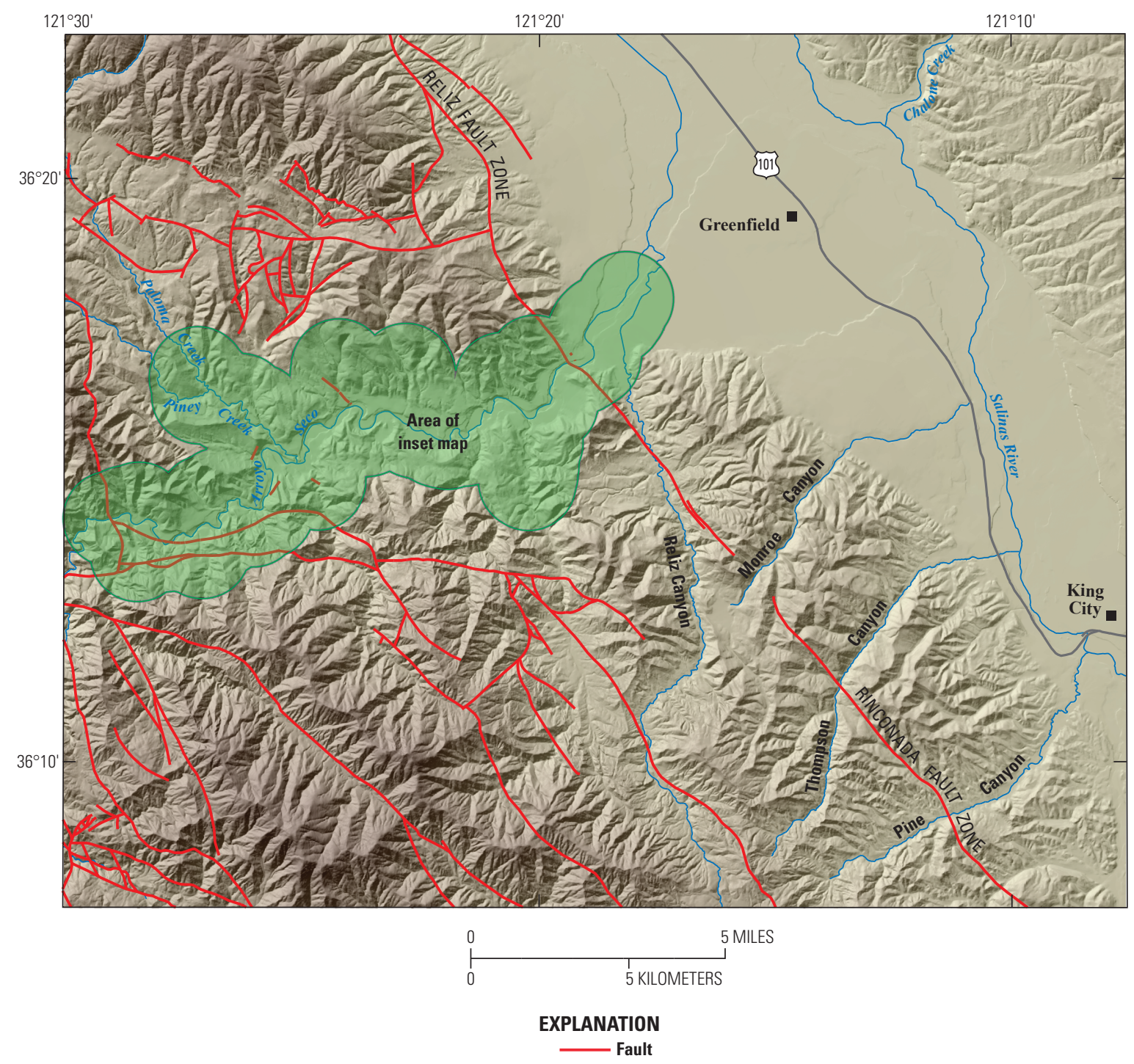

Figure 3. Location of Arroyo Seco inset map of Quaternary-age strath terraces. These terraces were eroded into Tertiary marine sediments in Arroyo Seco and the resulting sediments were deposited in the Salinas River valley. The Salinas River also provides a source for fine-grained sediments on the valley floor producing terrace and floodplain deposits at and adjacent to the river. 
Differences in the sense of displacement and amount of slip suggest that the Reliz and Rinconada faults are not a single continuous fault (Ross, 1984; Rosenberg and Clark, 2009). At least some of the strike-slip motion along the Rinconada fault zone may be transferred northwestward to the Tularcitos fault in the upper Carmel Valley (Rosenberg and Clark, 2009). Slip may be transferred along a complex assemblage of faults mapped in bedrock in the northern part of the map (Dunham, 1970); it was beyond the scope of this study to attempt to refine the magnitude and sense of offset on these faults.

\section{Description of Strath Terraces}

Strath terraces formed on the thick sequence of the Tertiary marine sediments preserve the incision history of Arroyo Seco. Older strath-terrace deposits are preserved as much as about $550 \mathrm{~m}$ above the modern drainage whereas younger deposits are from $150 \mathrm{~m}$ to $<1 \mathrm{~m}$ above the modern drainage (fig. 9, sheet 1). These terraces are capped by coarse, rounded granitic and metasedimentary cobbles and boulders exposed at the surface (figs. $4 A$ and $4 B$; fig. 7, sheet 1). The rounded stones are derived from the upstream resistant basement rocks. These gravelly, fluvial deposits are typically less than 2-m thick and lie unconformably on the Tertiary marine sediments. The contact between the fluvial deposits

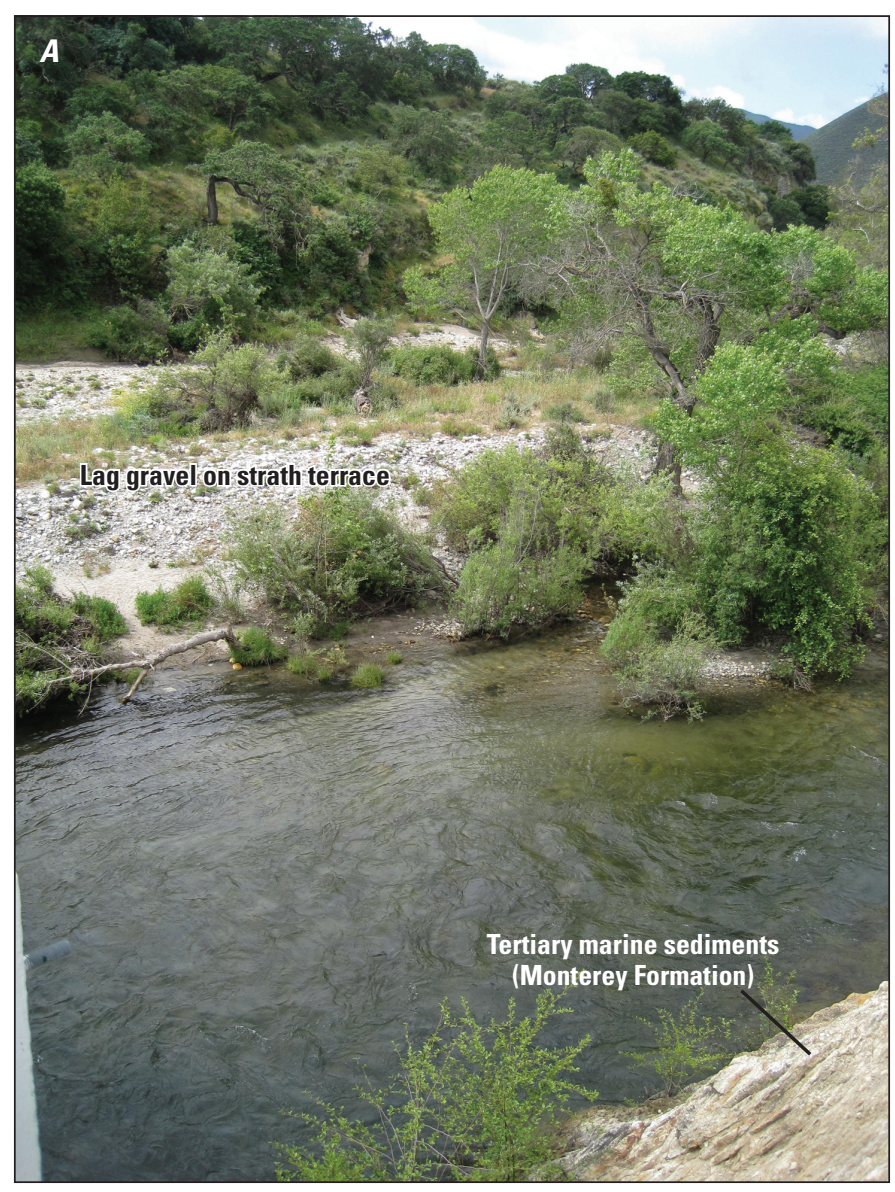

and the Tertiary marine sediments is clear and abrupt. Soils are developed on the fluvial deposits. Road cuts and natural exposures in Arroyo Seco also expose side-stream alluvium and colluvium that bury terrace gravel (fig. 5). Residual soils are also developed on the Tertiary marine sediments where the fluvial deposits are thin or eroded to thin lags. The residual soils may be welded with the overlying soil developed on the fluvial deposits.

The soils formed on the fluvial gravels demonstrate a clear progression of soil characteristics over time (fig. 6). Young soils are poorly consolidated and show little or no horizonation. Over time, clay-rich B horizons thicken and increase in secondary clay concentrations-from 0 to as much as 60 percent clay. As a result of increased clay concentration and secondary weathering, soil colors change from yellow brown (Munsell Color, 2009; 10YR), to reddish brown (7.5YR), to red (5YR) as deposits increase in age. The maximally developed $\mathrm{B}$ horizon also thickens from approximately 60 to $120 \mathrm{~cm}$ (table 2, sheet 1). In soils of middle Pleistocene age, metasedimentary clasts are decomposed in the maximally developed B horizon. The oldest soil in the mapped area has a silica-cemented horizon or duripan (fig. 6).

In many actively incising river canyons, gravel-capped bedrock strath terraces are tens to hundreds of meters above the active channel and extend discontinuously for kilometers. Long recognized as recording the former river bed and floodplain elevation, strath terraces, when dated, provide a direct means of quantifying rates of vertical bedrock river incision and are thus vital to studies of geomorphology, active tectonics, and the effects of climate change (Molnar and others, 1994).

Strath terraces represent ancient and now-abandoned river floodplains that formed during periods of valley-bottom widening and planation (DeVecchio and others, 2012). Bull (1990)

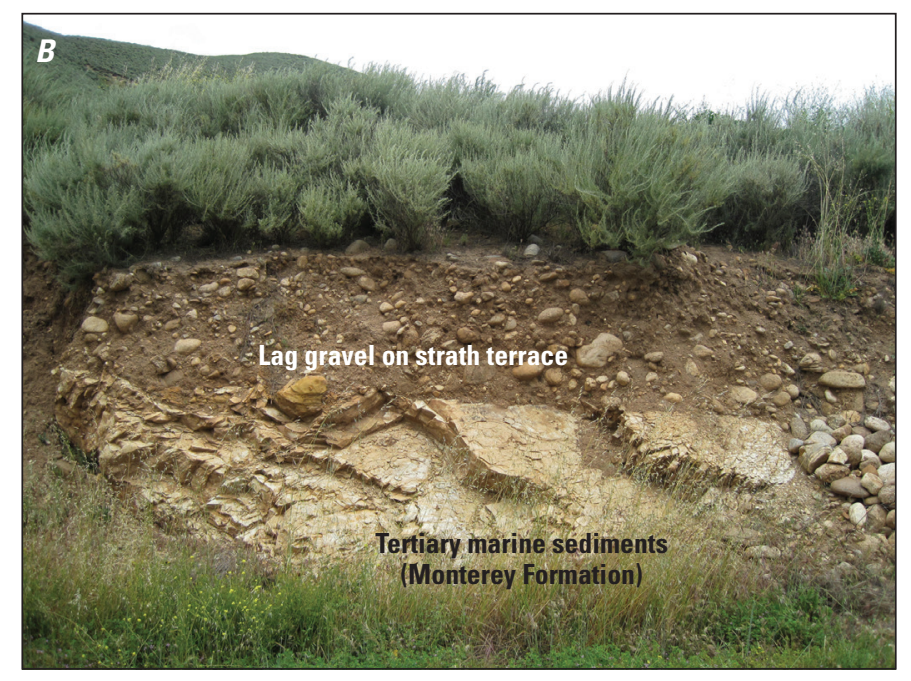

Figure 4. Photographs showing lag gravels and strath terraces. $A$, the active drainage is incising into the Tertiary marine sediments, leaving remnant lag gravel at the top of the eroded surface. $B$, strath terraces and associated soils preserve the same sequence that can be observed in Arroyo Seco today. 


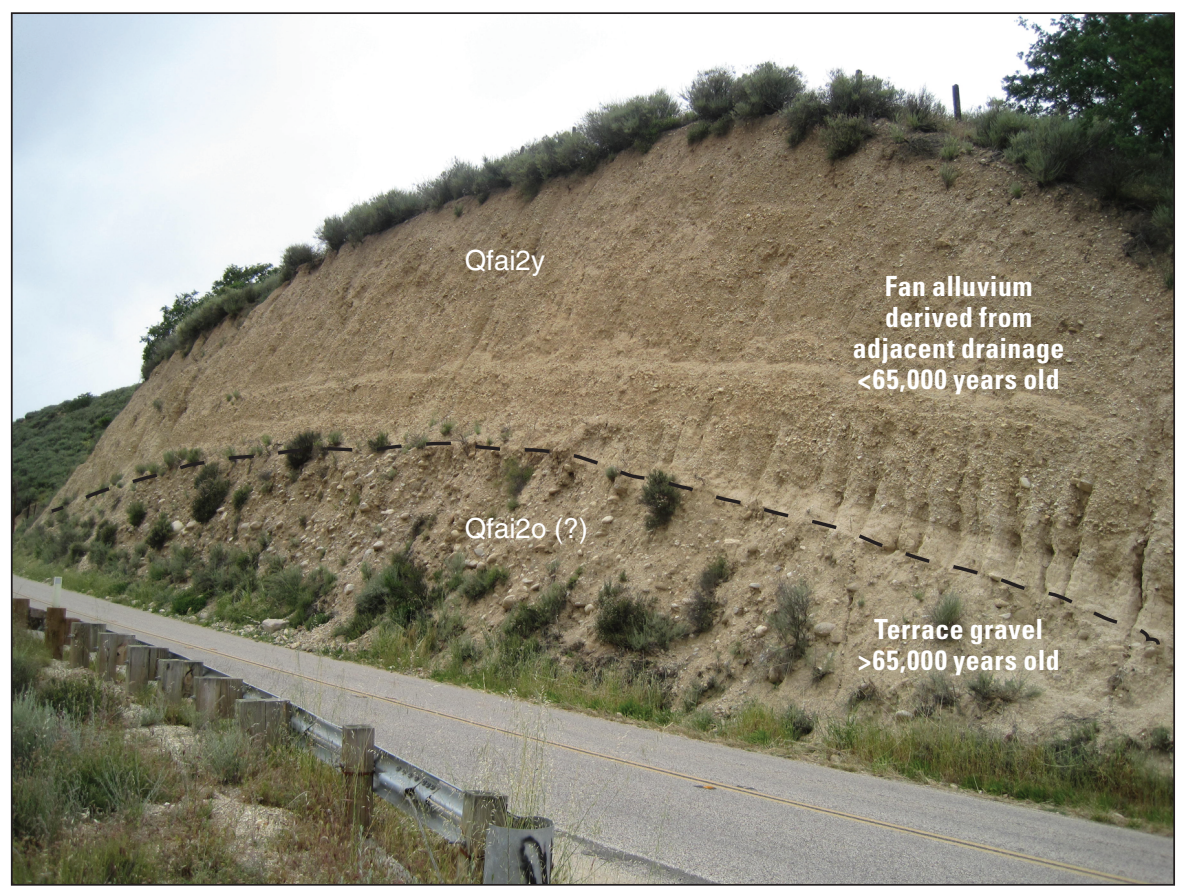

Figure 5. Buried terrace gravel exposed in road cut in Arroyo Seco. Buried terrace gravel was dated to determine the age of the buried deposit as well as the implied age of the alluvial fan.

suggested that lateral erosion and strath cutting are the dominant processes when streams are in dynamic equilibrium; that is, where river discharge and sediment load are in balance. Recent quantitative field studies and conceptual numerical models predict that strath terraces form in response to balanced or oscillating sediment supply, elevated sediment supply, and (or) periods of stable base level (Finnegan and Dietrich, 2011).

Explanations for why many incising rivers alternate between periods of dominantly lateral and dominantly vertical incision generally appeal either to temporal variation in baselevel stability or in the volume of coarse sediment supplied to rivers. For example, because gravel deposition in rivers armors the bed and suppresses vertical incision (Sklar and Dietrich, 2004), some propose that lateral channel shifting and strath terrace formation is favored during climatic periods of higher sediment supply relative to river transport capacity, whereas vertical incision is favored when sediment supplies are low relative to transport capacity (Molnar and others, 1994). Alternatively, because base-level stability forces a river to remain at one elevation, others propose that either tectonic quiescence punctuated by periodic uplift or sea-level rise and fall superimposed on steady tectonic uplift (Pazzaglia and Gardner, 1993) can generate flights of strath terraces.

Aggradation, during the onset of dry warm climatic cycles, results from increased sediment supply in response to transient vegetative conditions and consequent hillslope destabilization (Bull, 2007). Similar to aggradation events, strath terrace sediment ages may correlate to periods of dry, warm climate (DeVecchio and others, 2012). Increased sediment flux and decreased water discharge enhance lateral erosion rates and inhibit vertical incision. Subsequent incision, abandonment and strath terrace formation is inferred to occur during intervening wet climate intervals. In the western Transverse Ranges, where DeVecchio and others (2012) dated the strath terraces, they correlated strath terrace ages and aggradational events with environmental changes that are linked to global climate, indicating that climate rather than tectonics exhibits first-order control of depositional, denudational, and incisional processes.

\section{Methods}

The tools used to construct this geologic map were field work in combination with digital terrain analysis, stream gradient profiles, evaluation of published regional soil maps, and satellite imagery. Initial field work demonstrated that unique soils existed on both terrace and alluvial fan deposits, and that Arroyo Seco terrace surfaces could be correlated to alluvial fan deposits in the Salinas River valley.

Terrace-tread slopes were calculated from a 10-m digital elevation model using a geographic information system (GIS). Slopes less than 10 degrees were mapped and polygons were drawn around the individual surfaces. After measuring the elevation on each mapped terrace polygon, a longitudinal profile was constructed of all terrace surfaces along Arroyo Seco (fig. 7). Longitudinal profiles are measures of surface elevations along a stream gradient. Longitudinal profiles were also constructed on the other two major drainages in the map areaReliz Canyon and the Salinas River. Based on these profiles, terrace surfaces were correlated along Arroyo Seco. Twenty unique terraces were mapped from the point at which Arroyo Seco 


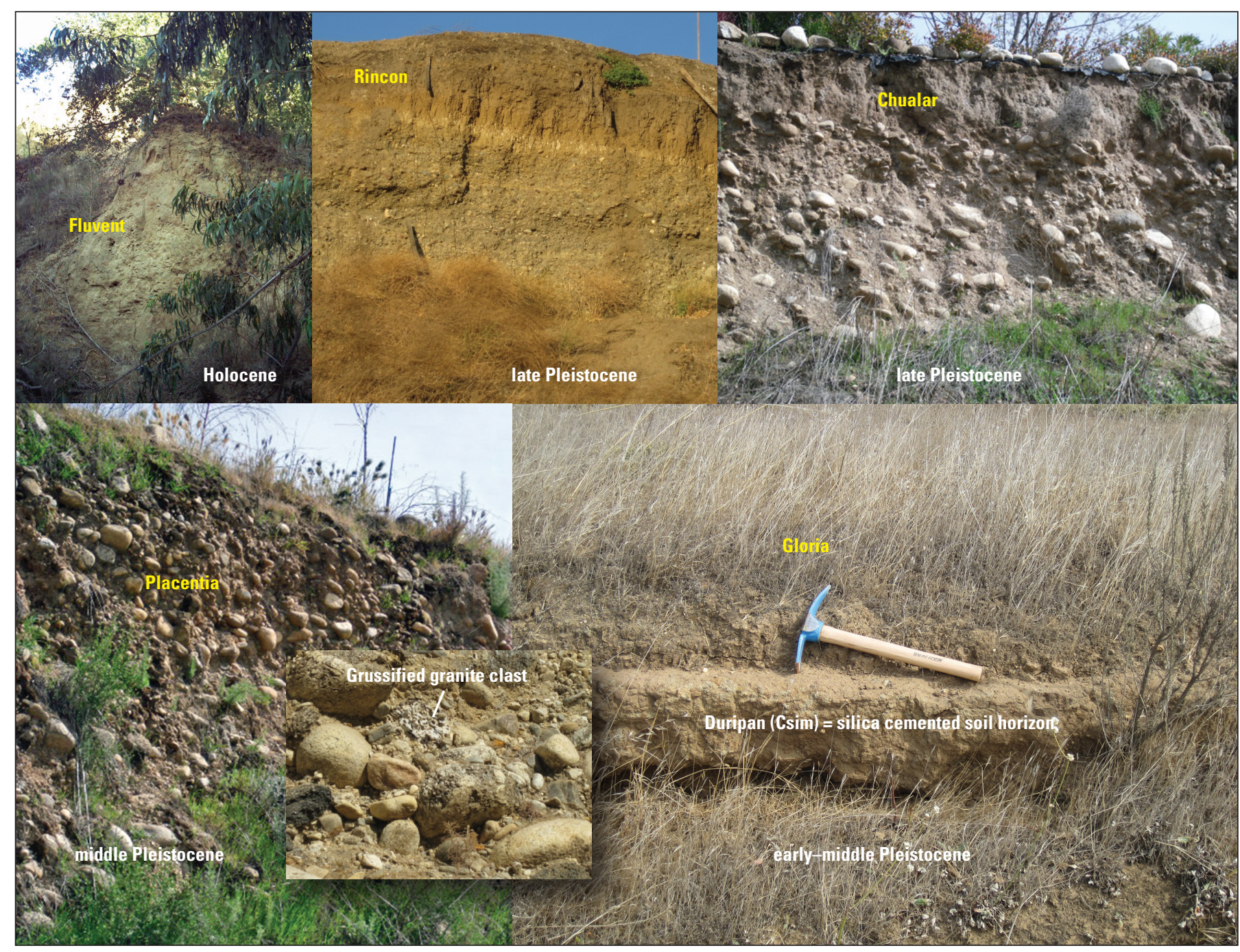

Figure 6. Unique soils are developed on the terrace surfaces. After deposition and fluvial abandonment, soils develop redder and thicker B horizons. These B horizons become increasingly cemented over time. Once intact gravel weathers to grus, only scattered and larger clasts are visible on the surface of the deposit. These photographs are typical of common soils (names in yellow) developed on different-aged deposits (table 2, sheet 1).

emerges from the narrow bedrock canyon to the intersection of Arroyo Seco with the Salinas River valley. Where Arroyo Seco enters the Salinas River valley, fluvial material is deposited and alluvial fans are formed. These fans were correlated to terrace surfaces based on elevation and soil development.

The soil map of Monterey County (Cook, 1978), in digital format [U.S. Department of Agriculture (USDA), 2009], was used to examine the soils developed on each of the unique terrace units. Soils were combined and simplified so that each map unit had a primary characteristic soil or set of soils (table 1, sheet 1). A preliminary geologic map that included both map units and soil types was used for field investigations to check units for consistency. Map-unit ages were initially assigned based on relative soil characteristics on Quaternary depositional units. Soils and bedrock units were observed in natural and existing manmade exposures. Field work focused on discrepancies between map units and soils-locations where soils were mapped on map units that seemed too old or too young based on the stratigraphic position of the unit. The final map product includes both the map unit and the soil developed on the unit (table 1, sheet 1). Note that soil units may be mapped on more than one map unit, and conversely, the same map unit may have more than one soil unit. Soil units are not mapped on oldest strath terraces (Qfo1-Qfo8) because original soil mappers did not recognize high terraces as being capped in alluvial gravel and only mapped residual soil.

Eight sediment samples were collected to determine age by infrared stimulated luminescence (IRSL) or optically stimulated luminescence (OSL) (S. Mahan, written commun., USGS, 2012) (table 1, sheet 1; table 3, sheet 2). All samples were collected at the base of the soil profile in the unweathered $\mathrm{C}$ horizon. Surface soils were sampled with the exception of AS10-9-6 that was sampled in a terrace gravel buried by an alluvial fan and exposed in a road cut in Arroyo Seco (fig. 5). See detailed geologic map for site locations and unit descriptions for discussion. 


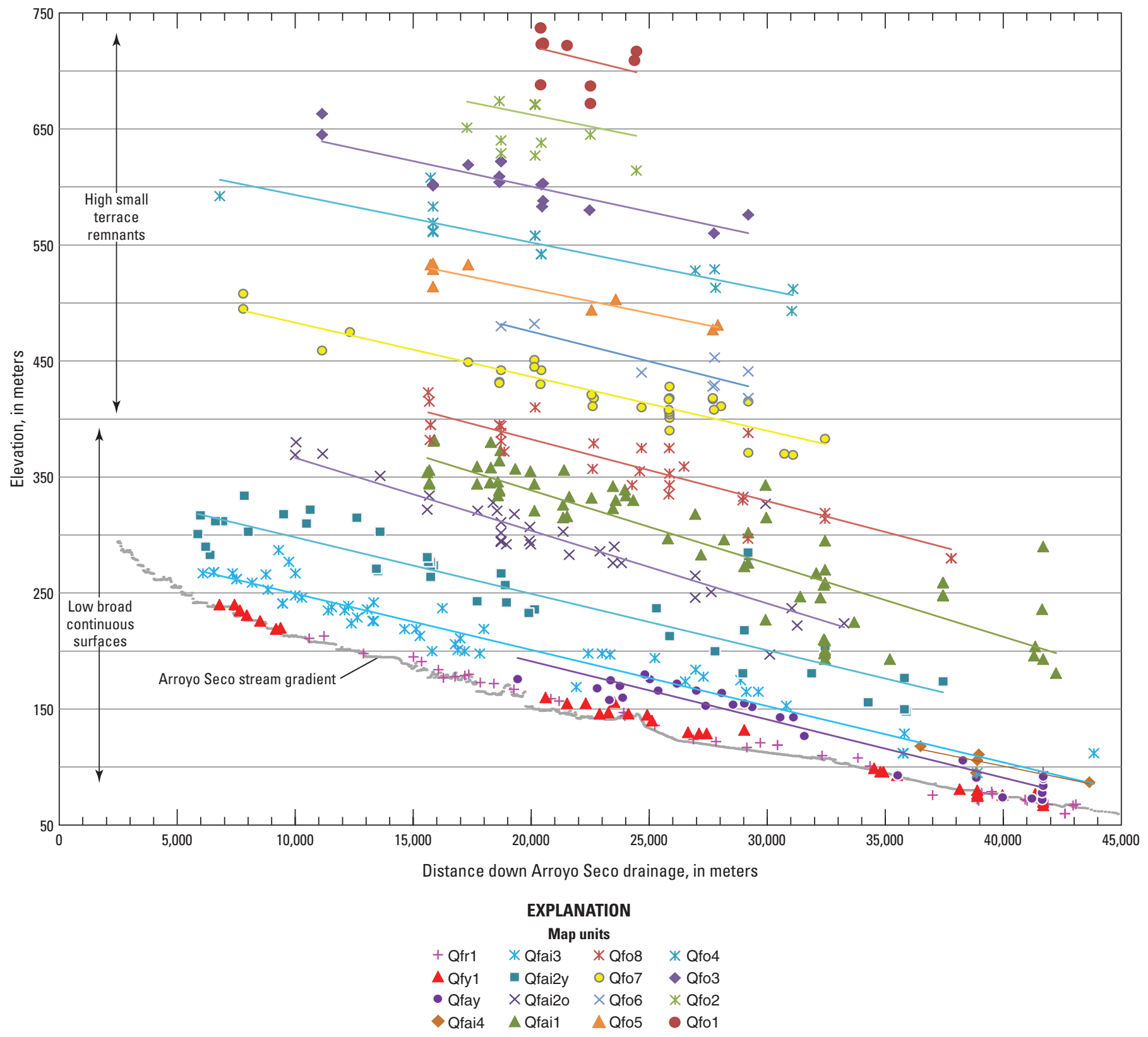

Figure 7. Stream gradient profile of terrace surfaces along Arroyo Seco. Different colored symbols represent different terrace surfaces. Terraces are approximately parallel and range in elevation from 800 to $100 \mathrm{~m}$ above sea level. 


\section{Discussion and Summary}

Mapped strath terraces in the vicinity of Arroyo Seco record an erosion history from the early Pleistocene to latest Holocene. Alluvial fans adjacent to the range front and extending to the central Salinas River valley can be correlated to erosional surfaces in Arroyo Seco using soils and streamgradient profiles. Young terrace and floodplain deposits can be observed at and adjacent to Arroyo Seco and Salinas River. This suite of erosional and depositional units can be used to generalize the Quaternary history of Arroyo Seco.

Prior to the cessation of the deposition of the Paso Robles Formation (QTpr), an ancestral drainage was eroding the broad paleoerosional surface north of Arroyo Seco (fig. 1, sheet 1). The highest (oldest) deposits (Qfo1-Qfo5) record stream erosion and deposition prior to Arroyo Seco valley incision. Isolated now in the Sierra de Salinas, this paleoerosional surface forms a gently sloping, low-relief geomorphic surface northwest of Arroyo Seco. Like Arroyo Seco, this paleoerosional surface is constrained by basement rocks and lies on the more easily erodible Tertiary marine sediments. Bounded by a complex web of faults on all sides, these isolated erosional remnants are no longer linked to a large active drainage but record a paleodrainage now abandoned and superseded by the Arroyo Seco system. What remain as possible linked drainages are the greatly undersized Paloma and Piney Creeks (fig. 3). Individual erosional surfaces of the ancestral drainage (units Qfo1-Qfo5) tend to decrease in elevation in a northwestward direction. If higher surfaces truly are older than lower surfaces, the mapping suggests a general northwest trend in surface age, linking the paleoerosional surface to the headwaters of the Carmel Valley drainage (Tularcitos Creek). Today the Carmel Valley drainage is separated from the paleoerosional surface by a low divide. An alternative interpretation would link the paleoerosional surface to a drainage flowing southeast prior to the inception of Arroyo Seco, and surface age is convoluted by faulting that surrounds the surfaces, and (or) northwestward tilting. The fan shape of the paleoerosional surface, which extends to the northwest out of the map area, supports a southeast flow direction. The apex of the fan occurs approximately at the divide.

The timing of formation and isolation of strath deposits in Arroyo Seco, which postdate the formation of the paleoerosional surface, was likely controlled primarily by paleoclimatic events and secondarily by tectonics. Contributions to terrace formation that were driven by faulting would have to be attributed to the Rinconada fault because of the lack of evidence for Quaternary movement on the Reliz fault. Fault-related uplift may occur through the transfer of slip onto other faults in the Santa Lucia Range or by transpressive crustal shortening across the Santa Lucia Range (Dickinson, 2005). Net Neogene crustal shortening across the northern Santa Lucia Range of 10-12 percent (Dickinson, 2005) could result in $2.2-2.7 \mathrm{~km}$ of bedrock uplift, corresponding to a $0.7-0.9 \mathrm{~mm} / \mathrm{yr}$ tectonic component of the bedrock uplift (Ducea and others, 2003). The absolute ages of the terraces in Arroyo Seco would be a valuable tool for establishing the magnitude of Quaternary uplift rates in the Santa Lucia Range. During this period of vertical movement, the level of the ocean has not remained the same. Changes in sea level are primarily produced by climate factors, but tectonics can also be a contributing factor. Taken together, these factors give rise to a complex pattern of continental erosion and deposition, which in this study are expressed as a sequence of strath terraces and associated alluvial fans in Arroyo Seco. DeVecchio and others (2012) have dated strath terraces at 110-100 ka, 50-35 ka, 26-20 ka and 15-4 ka in the southern California Transverse Ranges and correlated these depositional events to the onset of dry, warm climate cycles. The OSL and IRSL dates on seven individual terraces and associated alluvial fans in Arroyo Seco are approximately $>120 \mathrm{ka},>65 \mathrm{ka}$, 51-46 ka, $35 \mathrm{ka}, 9 \mathrm{ka}$, and 2-1 ka (table 1, sheet 1). These dates generally fall within the range of ages reported from the Transverse Range, which has a similar climate to that of Arroyo Seco. DeVecchio and others (2012) support the interpretation that decreased vegetation and water during dry warm climate intervals causes increased sediment flux and increased lateral erosion. Incision and strath terrace formation is inferred to occur during wet climate cycles. In these similar tectonically active environments, climate rather than tectonics is the more influential factor in "deposition, denudation, and incision processes" (DeVecchio and others, 2012).

No terrace in Arroyo Seco is correlative with the older and higher paleoerosional surface. It can be assumed that the drainage, in its current location, did not exist when the paleoerosional surface was formed. Any alluvial fans in the Salinas River valley that may have been associated with the erosion of the paleosurface are long buried by younger fans. The oldest strath terrace remnants (Qfo6-Qfai2), confined to the Arroyo Seco drainage, are preserved as a wide strand across the now-confined valley. Based on the mapped distribution of the strath terraces, this older, much broader drainage was probably a braided stream, indicating a steep gradient with a high flow-velocity. Over time, the gradient decreased and the drainage became confined to a meandering stream (Qfai3-Qfr). Meandering streams flow in low gradient, low flow-velocity environments (Schumm and others, 2000).

Stacked and matching terraces across the Arroyo Seco drainage record an erosional history beginning in the early Pleistocene with the inception of the current drainage. Soils developed on these terraces can be used to constrain the timing of terrace formation and remnant fluvial deposition on eroded bedrock. Base-level change, driven by climate change, is the major contributor to terrace formation in Arroyo Seco.

\section{Acknowledgments}

This mapping was funded by the USGS National Cooperative Geologic Mapping Program. Constructive reviews of the draft by Lew Rosenberg and Marith Reheis greatly improved the quality of the map. Paco Van Sistine helped to add internal consistency to the attributes of the Geographic Information Systems data. Thank you to Tony Garcia (California State University, San Luis Obispo) for contribution of the panoramic photograph of the Arroyo Seco. 


\section{DESCRIPTION OF MAP UNITS}

Qcb Cut bank (latest Holocene) - Steep exposed bluffs on active drainages

Qfr2 Fluvial and minor eolian deposits (latest Holocene) - Active channel, floodplain including gravel and sand bars, and modern dunes at and adjacent to the distal floodplain of Arroyo Seco and adjacent to the Salinas River with little or no vegetation. Soils are gravelly to sandy Entisols with no horizon development

Qfr1 Fluvial deposits (latest Holocene)-Terrace and floodplain deposits, $<1 \mathrm{~m}$ above the active channel of Arroyo Seco and Salinas River with sparse vegetation. Soils are sandy Entisols with no horizon development (see Fluvent photo, fig. 6)

Qfy2 Fluvial deposits (late Holocene) - Terrace and floodplain deposits $<2 \mathrm{~m}$ above the active channel of the floodplain of Arroyo Seco and Salinas River. Soils are fine-loamy Mollisols with an A/C profile

Qfy1 Fluvial deposits (late Holocene) —Terraces adjacent to Arroyo Seco, $<3 \mathrm{~m}$ above the active channel, prograding to minor terrace remnants on the floodplain where unit may interfinger with Qfr1. Within Arroyo Seco, deposit often hosts large, established sycamore trees and unit Qfy1 has been dated at about 1,000 years old (table 3, sheet 2; see Fluvent photo, fig. 6). Terraces also occur as remnants $<7 \mathrm{~m}$ above the active channel of the Salinas River. Soils are sandy Entisols with an A/C profile

Qfay Fluvial and alluvial deposits (middle to early Holocene) - Strath terraces on Arroyo Seco that prograde to alluvial fans. Alluvial deposits enter the Salinas River valley and bury older fan deposits and are dated at 9,570 \pm 650 years old (table 3, sheet 2). Alluvial fans have been eroded by younger Qfy1 and Qfy2 deposits. Inset alluvial terraces of Qfay age also occur along Chalone Creek on the east side of the Salinas River valley. No Qfay is mapped south of Arroyo Seco. Soils are coarse-loamy Mollisols with an A/C profile

Fluvial and alluvial deposits (latest late Pleistocene) - Alluvial fans and terraces, adjacent to both Arroyo Seco and Salinas River. Deposit is often a thin mantle $<2 \mathrm{~m}$ thick over Qfai3 at and adjacent to the range front. Qfai4 was dated but the age, $8,770 \pm 350$ years old (table 3, sheet 2), is not consistent with the soil formed on the deposit and the deposits close proximity in depositional timing to Qfai3. The deposit is probably between 20,000 and 30,000 years old. Qfai4 occurs as a strath terrace on the east side of the Salinas River, and in Arroyo Seco about $30 \mathrm{~m}$ above the active floodplain. Exposures of Qfai4 extend only about $7 \mathrm{~km}$ west of the intersection of Arroyo Seco with the Salinas River valley. Soils are clayey Alfisols with an A/Bt/C profile. Bt horizon has a brownish hue (10YR) with about 45 percent clay. High clay content in maximally developed B horizon (table 2, sheet 1; Rincon soil series) may result from contributions of fine-grained overbank flood deposits. Secondary carbonate is infrequently observed in the $\mathrm{C}$ horizon (see Rincon photo, fig. 6)

Fluvial and alluvial deposits (latest late Pleistocene) - Alluvial fans and strath terraces associated with Arroyo Seco and Reliz Canyon. Qfai4 and Qfai3 are the dominant inset terraces along the meandering Arroyo Seco and very little time separates the deposition of these two units. Where Qfai3 forms strath terraces in Arroyo Seco it is about $40 \mathrm{~m}$ above the active drainage and where it forms alluvial fans it is about $10 \mathrm{~m}$ above Qfai4. Qfai3 alluvial fans are buried by unit Qfay near the confluence of Arroyo Seco and Reliz Canyon. Remnants of the Qfai3 strath terraces extend the entire length of Arroyo Seco. Qfai3-age deposits surround the abandoned oxbow lake near the canyon mouth of Arroyo Seco, near the western map edge, suggesting that the meander sweep was abandoned after the erosion of Qfai3. Qfai3 is dated at 35,350 \pm 3,680 years old (table 3, sheet 2). Soils are predominantly loamy alluvial Mollisols with an $\mathrm{A} / \mathrm{Bt} / \mathrm{C}$ profile. Bt horizon has a brown (10YR) to reddish hue (7.5YR) with 25-35 percent clay (See Chualar photo, fig. 6)

Eolian deposits (latest late Pleistocene) - Eolian sand dunes modified to terraces, about 30-40 m above the active floodplain of the Salinas River. Deposit is east of the Salinas River, and has been eroded by Qfai4-age deposits. This deposit is also southeast of the town of King City, just east of the mapped area. Soils are loamy sandy Alfisols with an $\mathrm{A} / \mathrm{Bt} / \mathrm{C}$ profile. Bt horizon has a brownish (10YR) to reddish hue (7.5YR) with 15 percent clay

Qfai2y Fluvial and alluvial deposits (latest late Pleistocene)-Alluvial fans and strath terraces. A Qfai2y terrace in Arroyo Seco is dated at 50,640 $\pm 2,980$ and 45,960 $\pm 1,840$ years old (table 3, sheet 2). The erosional event associated with the formation of Qfai2y was indirectly dated at $<65,000$ years old because a Qfai2y alluvial 
fan buried a terrace gravel that was dated at $>65,000$ years old (fig. 5). Qfai2y is about $80 \mathrm{~m}$ above the modern drainage. Qfai2y forms a predominant range-front alluvial fan south of Arroyo Seco. Soils are loamy alluvial Mollisols with an $\mathrm{A} / \mathrm{Bt} / \mathrm{C}$ profile. Bt horizon has a brownish hue (10YR) with about 35 percent clay

Qfai2o Fluvial and alluvial deposits (latest late Pleistocene) - Strath terraces in Arroyo Seco. Terraces are typically remnants located above the modern drainage and large strath terraces within the meandering drainage. Buried Qfai2o terrace deposits were dated at $>65,000$ years old. Soils are the same as those on Qfai2y indicating very little time between the abandonment of Qfai2o and Qfai2y

Qfai1 Fluvial and alluvial deposits (early late Pleistocene) - Strath terraces in Arroyo Seco formed on the Tertiary marine sediments and Paso Robles Formation. Terraces form dramatic erosional features on both the east and west sides of the Salinas River valley, including the range front where Arroyo Seco intersects the broad valley. These terraces, and all older terraces, lack the general meandering nature of the younger terraces and were created in a much broader alluvial floodplain than today. This broader floodplain was probably a braided drainage system suggesting a higher velocity drainage than the current meandering system. Soils are typically coarse-loamy Mollisols and Alfisols developed on granitic alluvium with an $\mathrm{A} / \mathrm{Bt} / \mathrm{C}$ profile (see Placentia photo, fig. 6). The Bt horizon has a brown (10YR) to darker reddish-brown hue (5YR). Qfai1 also includes silty and clayey residual soils, developed on both Tertiary marine sediments and the Paso Robles Formation. These soils have an A/C profile

Alluvial deposits (late middle Pleistocene) - Alluvial fans flanking range front north of Arroyo Seco, extending north of the mapped area on the east and west sides of the Salinas River valley. Soils are coarse-loamy Alfisols developed on granitic alluvium with an $\mathrm{A} / \mathrm{Bt} / \mathrm{Csim}$ profile. Silica cementation in the $\mathrm{C}$ horizon, called a duripan (Csim), is extremely hard when dry and does not slake during prolonged soaking in water. The Bt horizon has a reddish-brown (7.5YR) to darker reddish-brown hue (5YR) (see Gloria photo, fig. 6)

Qfo8-1 Fluvial deposits (middle to early Pleistocene) - Strath terraces Qfo8-Qfo1 on Tertiary marine sediments. Stranded or isolated Arroyo Seco terrace treads capped by rounded granitic cobbles to boulders. Terraces are on both sides of the drainage. All surfaces have a less than 10 degree slope. Individual remnants of units Qfo8-Qfo1 are correlated by stream gradient profile interpretations (fig. 7). Older surfaces (Qfai1 and older) record a broader, high flow-velocity, steep gradient, braided stream in Arroyo Seco that has subsequently evolved into the current meandering drainage

QTpr Paso Robles Formation (middle Pleistocene to Pliocene) - Unconsolidated to poorly consolidated heterogeneous coarse sand and gravel, as well as interbedded finer sand, silt, and clay. Coarse fragments are primarily siliceous shale of the Monterey Formation. Environment of deposition is fluvial and includes some debris flows and lacustrine deposits. Datable tephra layers are interbedded with clastic strata. Tephra samples from the Paso Robles Formation in the Gabilan Range include the Nomlaki Tuff ( $3.4 \pm 0.4 \mathrm{Ma})$ and the Lawlor Tuff (4.1 $\pm 0.2 \mathrm{Ma})$ (Sarna-Wojcicki and others, 1991). The Paso Robles Formation is exposed in the hills on the east and west sides of the Salinas River valley. On the east, it overlies unit MzPzub (undifferentiated basement) and on the west Tertiary marine sediments (Tms). Unit is commonly capped by erosional strath terraces. Ranges in thickness from 60 to $600 \mathrm{~m}$

Tsa Shallow nearshore marine regressive sediments (Pliocene)_Informal sandstone of San Ardo. Sandstone, light gray, friable, medium grained, vaguely bedded, contains shell fragments. Unit occurs along the range front where Arroyo Seco intersects the Salinas River valley and in Reliz Canyon

Tpr Pancho Rico Formation (Pliocene to Miocene) - Siltstone, light gray diatomaceous mudstone to fine-grained silty sandstone, vaguely bedded. Shallow-marine, estuarine, and lagoonal sediments. In the map area, Tms occurs on the west side of the Salinas River valley, however, south of the map area, the Pancho Rico Formation flanks the east side of the Salinas River valley

Tms Tertiary marine sediments (Miocene to Paleocene) - Primarily Monterey Formation. Siliceous shale and sandstone. Shale is white to gray, thinly bedded, soft to hard, platy, contains thin, hard layers of limestone. Abundant fish fossils. Sandstone is light gray to tan, massive to thick-bedded, medium-grained, arkosic. Includes a small outcrop of Paleocene to Eocene Reliz Canyon Formation south of Arroyo Seco

MzPzub Undifferentiated basement rocks (Mesozoic to Paleozoic)—Plutonic basement, primarily granitic rocks, and metasedimentary rocks, mostly schist and gneiss. Metasedimentary rocks are intruded by granitic rocks. Rounded granitic rocks derived from unit occur as field stones capping strath terraces (fig. 7, sheet 1) 


\section{References Cited}

Bull, W.B., 1990, Stream-terrace genesis: Implications for soil development: Geomorphology, v. 3, p. 351-367, doi: 10.1016/0169-555X(90)90011-E.

Bull, W.B., 2007, Tectonic Geomorphology of Mountains: A New Approach to Paleoseismology: Oxford, Blackwell Publishing, $316 \mathrm{p}$.

Cook, T.D., 1978, Soil survey of Monterey County, California: U.S. Department of Agriculture, Soil Conservation Service, $229 \mathrm{p}$.

DeVechio, D.E., Heermance, R.V., Fuchs, Markus, and Owen, L.A., 2012, Climate-controlled landscape evolution in the Western Transverse Ranges, California: Insights from Quaternary geochronology of the Saugus Formation and strath terrace flights: Lithosphere, v. 4, no. 2, p. 110-130, doi: 10.1130/L176.1.

Dibblee, T.W., Jr., 1973, Stratigraphy of the southern Coast Ranges near the San Andreas Fault from Cholame to Maricopa, California: U.S. Geological Survey Professional Paper 764, 45 p.

Dibblee, T.W., Jr., and Minch, J.A., ed., 2006a, Geologic map of the Junipero Serra Peak quadrangle, Monterey County, California: Santa Barbara, Dibblee Geological Foundation Map DF-248, scale 1:24,000.

Dibblee, T.W., Jr., and Minch, J.A., ed., 2006b, Geologic map of the Paraiso Springs quadrangle, Monterey County, California: Santa Barbara, Dibblee Geological Foundation Map DF-247, scale 1:24,000.

Dibblee, T.W., Jr., and Minch, J.A., ed., 2006c, Geologic map of the Reliz Canyon quadrangle, Monterey County, California: Santa Barbara, Dibblee Geological Foundation Map DF-249, scale 1:24,000.

Dibblee, T.W., Jr., and Minch, J.A., ed., 2006d, Geologic map of the Sycamore Flat quadrangle, Monterey County, California: Santa Barbara, Dibblee Geological Foundation Map DF-246, scale 1:24,000.

Dibblee, T.W., Jr., and Minch, J.A., ed., 2006e, Geologic map of the Thompson Canyon quadrangle, Monterey County, California: Santa Barbara, Dibblee Geological Foundation Map DF-250, scale 1:24,000.

Dibblee, T.W., Jr., and Minch, J.A., ed., 2007, Geologic map of the Greenfield quadrangle, Monterey County, California: Santa Barbara, Dibblee Geological Foundation Map DF-307, scale 1:24,000.

Dickinson, W.R., Ducea, Mihai, Rosenberg, L.I., Greene, H.G., Graham, S.A., Clark, J.C., Weber, G.E., Kidder, Steven, Ernst, W.G., and Brabb, E.E., 2005, Net dextral slip, Neogene San Gregorio-Hosgri fault zone, coastal California: Geologic evidence and tectonic implications: Geological Society of America Special Paper 391, 43 p.
Dohrenwend, J.C., 1974, Plio-Pleistocene geology of the central Salinas Valley and adjacent uplands, Monterey County, California: Stanford, Calif., Stanford University, Ph.D. dissertation, $274 \mathrm{p}$.

Dohrenwend, J.C., 1979, Provenance and paleodrainage of the northern part of the Paso Robles Formation, Monterey County, California, in Graham, S.A., ed., Tertiary and Quaternary geology of the Salinas Valley and Santa Lucia Range, Monterey County, California: Society of Economic Paleontologists and Mineralogists, Pacific Section, Pacific Coast Paleogeography Field Guide 4, p. 77-82.

Ducea, M.N., House, M.A., and Kidder, Steven, 2003, Late Cenozoic denudation and uplift rates in the Santa Lucia Mountains, California: Geology, v. 31, no. 2, p. 139-142.

Durbin, T.J., Kapple, G.W., and Freckleton, J.R., 1978, Twodimensional and three-dimensional digital flow models of the Salinas Valley ground-water basin, California: U.S. Geological Survey Water-Resources Investigations Report 78-113, $134 \mathrm{p}$.

Durham, D.L., 1963, Geology of the Reliz Canyon, Thompson Canyon, and San Lucas quadrangles, Monterey County, California: U.S. Geological Survey Bulletin 1141-Q, scale $1: 24,000$.

Durham, D.L., 1970, Geology of the Sycamore Flat and Paraiso Springs quadrangles, Monterey County, California: U.S. Geological Survey Bulletin 1285, 34 p., 4 pls.

Durham, D.L., 1974, Geology of the southern Salinas Valley area, California: U.S. Geological Survey Professional Paper 819, 111 p., 4 pls.

Finnegan, N.J., and Dietrich, W.E., 2011, Episodic bedrock strath terrace formation due to meander migration and cutoff: Geology, v. 39, p. 143-146, doi: 10.1130/G31716.1.

Gibbard, P.L., Head, M.J., Walker, M.J.C., and The Subcommission on Quaternary Stratigraphy, 2010, Formal ratification of the Quaternary System/Period and the Pleistocene Series/Epoch with a base at $2.58 \mathrm{Ma}$ : Journal of Quaternary Science, v. 25, issue 2, p. 96-102.

Graham, S.A., 1978, Role of Salinian block in evolution of San Andreas Fault system, California: American Association of Petroleum Geologists Bulletin, v. 62, p. 2,214-2,231.

Mahan, S.A., and Brown, D.J., 2007, An optical age chronology of late Quaternary extreme fluvial events recorded in Ugandan dambo soils: Quaternary Geochronology, v. 2, issues $1-4$, p. 174-180.

Molnar, Peter, Brown, E.T., Burchfiel, B.C., Qidong, Deng, Xianyue, Deng, Jun, Li, Raisbeck, G.M., Jianbang, Shi, Zhangming, Wu, Yiou, Françoise, and Huichuan, You, 1994, Quaternary climate change and the formation of river terraces across growing anticlines on the north flank of the Tien Shan, China: Journal of Geology, v. 102, p. 583-602, doi: 10.1086/629700. 
Munsell Color, 2009, Munsell rock-color chart: Baltimore, Md., Kollmorgen Corp., Macbeth Division, http://www.munsellstore.com/files/CIPA00011/599.pdf.

Page, B.M., Coleman, R.G., and Thompson, G.A., 1998, Overview: Late Cenozoic tectonics of the central and southern Coast Ranges of California: Geological Society of America Bulletin, v. 110, no. 7, p. 846-876.

Pazzaglia, F.J., and Gardner, T.W., 1993, Fluvial terraces of the lower Susquehanna River: Geomorphology, v. 8, issues 2-3, p. 83-113, doi: 10.1016/0169-555X(93)90031-V.

Prescott, J.R., and Hutton, J.T., 1994, Cosmic ray contributions to dose rates for luminescence and ESR dating: Large depths and long-term time variations: Radiation Measurements, v. 23, p. 497-500.

Reed, R.D., and Hollister, J.S., 1936, Structural evolution of southern California: Tulsa, Oklahoma, American Association of Petroleum Geologists, v. 20, 157 p.

Rosenberg, L.I., and Clark, J.C., 2009, Map of the Rinconada and Reliz fault zones, Salinas River Valley, California: U.S. Geological Survey Scientific Investigations Map 3059, scale 1:250,000 with pamphlet, http://pubs.usgs.gov/ $\operatorname{sim} / 3059 /$.

Ross, D.C., 1984, Possible correlations of basement rocks across the San Andreas, San Gregorio-Hosgri, and Rinconada-Reliz-King City faults, California: U.S. Geological Survey Professional Paper 1317, 37 p.

Sarna-Wojcicki, A.M., Lajoie, K.R., Meyer, C.E., Adam, D.P., and Rieck, H.J., 1991, Tephrochronologic correlation of upper Neogene sediments along the Pacific margin, conterminous United States, in Morrison, R.B., ed., Quaternary nonglacial geology - Conterminous United States: Boulder, Colorado, Geological Society of America, The Geology of North America, v. K-2, p. 117-140.

Schumm, S.A., Dumont, J.F., and Holbrook, J.M., 2000, Active tectonics and alluvial rivers: Cambridge, U.K., New York, Cambridge University Press, 276 p.

Publishing support provided by:

Denver Publishing Service Center, Denver, Colorado

For more information concerning this publication, contact:

Center Director, USGS Geosciences and Environmental Change Science Center Box 25046, Mail Stop 980

Denver, C0 80225

(303) 236-5344

Or visit the Geosciences and Environmental Change Science Center Web site at: http://gec.cr.usgs.gov/

This publication is available online at:

http://dx.doi.org/10.3133/sim3260
Seiders, V.M., Joyce, J.M., Leverett, K.A., and McLean, Hugh, 1983, Geologic map of part of the Ventana Wilderness and the Black Butte, Bear Mountain, and Bear Canyon roadless areas, Monterey County, California: Miscellaneous Field Studies Map MF-1559-B, scale 1:50,000.

Sklar, L.S., and Dietrich, W.E., 2004, A mechanistic model for river incision into bedrock by saltating bed load: Water Resources Research, v. 40, issue 6, W06301, doi: 10.1029/2003WR002496.

Snetsinger, K.G., 1962, Late Tertiary and Quaternary history of the lower Arroyo Seco area, Monterey County, California: Stanford, Calif., Stanford University, unpub. M.S. thesis, 72 p., 4 pls.

Soil Survey Staff, 2010, Spatial and tabular data of the Soil Survey for Monterey County, California: United States Department of Agriculture, Natural Resources Conservation Service, http://websoilsurvey.nrcs.usda.gov. Also available at http://datagateway.nrcs.usda.gov/GDGOrder.aspx, Go to California $>$ Monterey County $>$ Soils, $>$ Soil Survey Spatial and Tabular Data (SSURGO 2.2), 2 maps 50.291 MB.

Tinsley, J.C., 1975, Quaternary geology of northern Salinas Valley, Monterey County, California: Stanford, Calif., Stanford University, Ph.D. dissertation, 390 p., 2 pls.

Tinsley, J.C., and Dohrenwend, J.C., 1979, Field trip roadlog, day 2-Aspects of Quaternary geology, central Salinas Valley, Monterey County, California, in Graham, S.A., ed., Tertiary and Quaternary geology of the Salinas Valley and Santa Lucia Range, Monterey County, California: Society of Economic Paleontologists and Mineralogists, Pacific Section, Pacific Coast Paleogeography Field Guide 4, p. 119-131.

U.S. Department of Agriculture (USDA), Natural Resources Conservation Service, 2009, Soil Survey Geographic (SSURGO) database for Monterey County, California: ca053, accessed February, 2010, at http://SoilDataMart. nrcs.usda.gov/. Now at http://websoilsurvey.sc.egov.usda. gov/App/HomePage.htm. 
